\title{
Behaviour of Square Footing Due to the Effect of Adjacent Excavation in Sand
}

\author{
Karthigeyan Shanmugam, Vishalatchi Ramasamy*, Abhirami Bindu \\ Department of Civil Engineering, College of Engineering Guindy, Anna University, Chennai, India \\ Email address: \\ mahamaha2001@yahoo.com (K. Shanmugam,), rmsvisha2010@gmail.com (V. Ramasamy), abhirami1002@gmail.com (A. Bindu) \\ ${ }^{*}$ Corresponding author
}

\section{To cite this article:}

Karthigeyan Shanmugam, Vishalatchi Ramasamy, Abhirami BinduB. Behaviour of Square Footing Due to the Effect of Adjacent Excavation in Sand. International Journal of Architecture, Arts and Applications. Vol. 7, No. 3, 2021, pp. 62-70. doi: 10.11648/j.ijaaa.20210703.12

Received: July 8, 2021; Accepted: August 9, 2021; Published: August 18, 2021

\begin{abstract}
In today scenario, urbanization and related infrastructure development in the form of an excavation adjacent to the existing structure are inevitable. In this case, the stability of an existing structure closer to the excavation is a serious concern. The main issue here is that, what is the safe distance at which new construction can take place from the existing structure? There are many research articles that states on the failure of an existing structure due to new construction adjacent to it in the form of excavations. Given the above, the paper presents the numerical results based on the finite element analyses that were performed for various parameters to examine the behaviour of existing square footing due to the effect of adjacent excavations in loose sand using PLAXIS3D software. In the finite element analysis, the behaviour of the footing and sheet pile walls were modelled using a linear elastic material and the elastoplastic behaviour of soil was modelled using a Mohr-Coulomb model under drained conditions. The literature available on this topic reveals that the excavation dimensions, shape of the footing, depth of the footing, location of the footing from the excavation, relative stiffness factor and relative density of sand are influencing the response of existing footing. Two different shapes of excavations such as a long length with narrow excavation under plane strain condition and short length of excavation under three-dimensional conditions were considered in this study. Numerical results indicate that the response of the square footing due to the effect of adjacent excavations are very much significant and mainly depends on the size of the excavation. The vertical and horizontal displacement, bending moment of the footing is increasing with an increase in depth of excavation. The footing located very closer to the excavation is significantly influenced as compared to the footing located far away from the excavation. The safe location of the square footing based on the settlement criteria is found to be $1.3 \mathrm{~m}$ from the excavation for shorter length excavation under three-dimensional conditions and $10 \mathrm{~m}$ for longer length of excavation under three-dimensional conditions.
\end{abstract}

Keywords: Excavation, PLAXIS 3D, Footing, Displacement, Stress

\section{Introduction}

Urban development has created various geotechnical challenges as the city keeps developing an infrastructure both vertically and horizontally. Further globalization urges us to include estimation of the ground movement as well as stability check of the braced and un-braced excavation in the wall design. Researchers have studied the finite element method with reduced shear strength technique to evaluate the $2 \mathrm{D}$ base stability of excavations and derived a relationship between the dimensions, distance and the soil parameters of the excavation and the displacements caused using the finite element method $[1,2]$. The study reveals that the ratio of the maximum ground surface settlement to the maximum wall movement decreases with increasing wall flexibility for the cantilever component but increase with increasing wall flexibility for the lateral bulging components [3]. A major concern, in this case, is to be proactive to reduce the damage to adjoining buildings and underground utilities by employing different retaining structures. The influence of excavations on the soil system is dependent on various parameters such as the depth to width ratio, the thickness of the soft soil layer between the excavation base and the hard stratum, the depth of walls inserted below the excavation base, the stiffness of the walls, and the length to width ratio of the excavation [4]. Even when the excavation base is of a supported type, the ground movement is majorly dependent on the thickness of the weak soil layer beneath the bottom of an excavation, the depth of the 
wall below the bottom of the excavation, and the stiffness of the wall. The displacement of soils beneath and around the bottom of the excavation was restrained when the rigid stratum was closer to the bottom of the excavation [5].

The minimum distance of excavation from the existing structure can be estimated based on allowable stresses and displacement of the ground by simulating the exact field situations, load and even construction procedure using the PLAXIS software [6]. The in-situ stresses on the ground are to be released due to excavations and the existing structures that present nearer to these grounds are subject to additional induced bending moments. Which may lead to structural distress and even failure in some cases. The main concern, in this case, is to prevent or minimize the damages to the existing structure due to ground movements caused by these adjacent excavations. For any given excavation, the magnitude and extent of the ground movement depend significantly on the soil properties, excavation geometry, the type of retaining wall with a support system and construction procedure. It was reported that the construction sequences also significantly affect the ground displacement and lateral stress behind the wall [7].

Case studies conducted by earlier researchers have shown the importance to analyse the effect of excavation on the existing footing and its response which is subjected to both vertical and lateral loading in terms of ground movements as shown in Figure 1. However, negligence of the same has led to losses that are fatal [8-10].

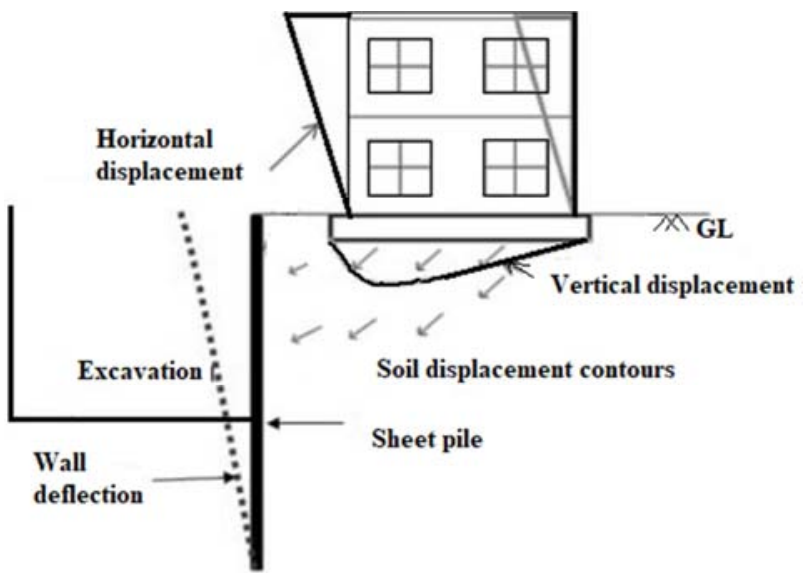

Figure 1. Schematic description of the problem.

Given the above, this paper is mainly focused on investigating the response of the square footing under the influence of induced ground movements due to adjacent excavation.

\section{Details of Numerical Analysis}

Series of numerical analyses were performed to investigate the response of square footings due to adjacent excavation using the PLAXIS 3D programme. In the analysis, the top view approach was used to model the project geometry i.e. model was outstretched in a vertical direction. Allowing detailed and accurate modelling, the material properties, construction stages and loadings were assigned based on the appropriate graphical user interface.
Initially, several trial analyses were carried out to choose the best possible combination of mesh for parametric study. The numerical scheme employed for the study was validated by comparing it with published experimental test results. Soil layers were defined through boreholes. In the analysis, the software allows automatic generation of 2D finite element mesh based on top view as shown in Figure 2. A 15 - node wedge element with a quadratic variation of displacement was used for simulating the soil continuum obeying a Mohr-Coulomb model under drained conditions.

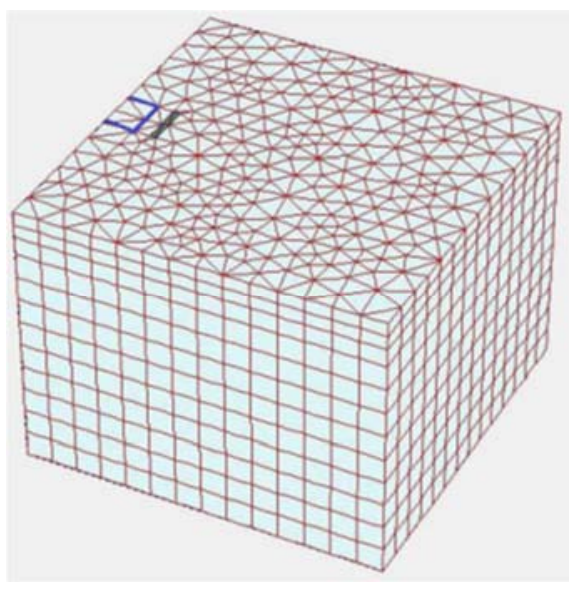

Figure 2. Typical 3D finite element mesh dimension.

\subsection{Validation of the Software}

Very limited works of literature are available similar to this work [11] and evaluated by a numerical study [12]. Based on the experimental study [11], model tests were conducted to evaluate the behaviour of a strip footing in the proximity of deep excavation induced lateral soil movements. The experimental test was carried out in two stages i.e. initially, the response of the strip footing was analyzed subjected to pure vertical loads. In the second stage, the response of the strip footing was analyzed with a combination of vertical load and excavation induced soil movements. The material properties of the soil, the footing and the sheet pile walls are being the same as reported in the paper. Figure 3 show the 3-D finite element mesh used for validation of the software with the published result.

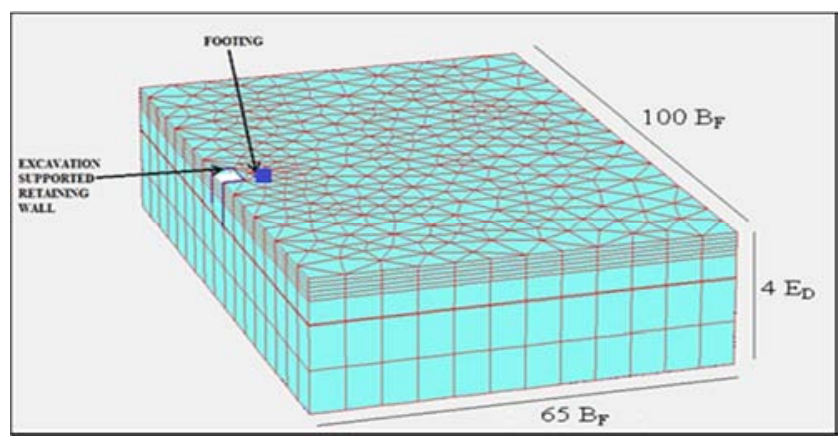

Figure 3. Three Dimensional finite element mesh.

Figure 4 shows the bearing pressure to displacement curve obtained using the PLAXIS3D software and an experimental test curve. It is seen from the figure that the predicted result is 
closely adhered with the experimental work by Mostafa et al (2013).

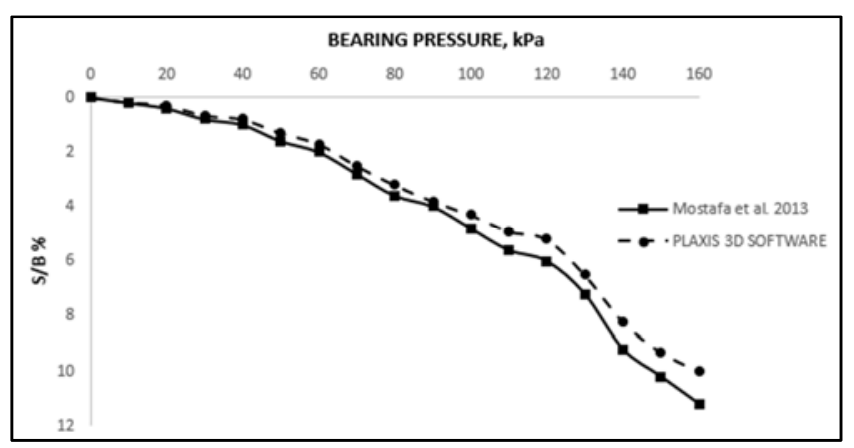

Figure 4. Bearing pressure Vs Displacement.

The numerical analyses were carried out in eight different phases. In the initial phase, the in-situ stresses were calculated by performing a $\mathrm{K}_{0}$ analysis. In phase I, the footing installation was simulated in the model. In phase II, vertical load was applied incrementally on the footing. In phase III, the sheet pile was inserted and phase IV to phase VIII, involves the removal of $1 \mathrm{~m}$ of soil in each step and continued until the desired depth of excavation was achieved.

\subsection{Parametric Study}

A series of three-dimensional finite element analyses have been carried out to investigate the behaviour of existing square footing due to the repercussion of an adjacent excavation by incorporating various design parameters. The various parameters considered in the analyses were the dimension of the excavation, depth of the excavation, the width of the footing, depth of the footing and shape of the footing. The vertical displacement, horizontal displacement and bending moment of the footing concerning various design parameters are interpreted from the numerical results.

All analyses were performed on concrete footings made up of M30 grade concrete [15]. The footings considered for the study were resting on loose homogeneous sandy soils with the angle of internal friction $30^{\circ}$. In all the numerical analyses, the footing was assumed to behave as a linear elastic material and the behaviour of soil was an elasto-plastic material obeying Mohr-Coulomb failure criterion and the sheet pile wall was a linear isotropic material. The details of the properties of soil, footing and the sheet pile walls used in the study are given in Table 1.

\section{Results and Discussions}

The numerical results were obtained from the parametric studies on the square footing concerning the effect of various parameters are discussed in the following section.

\subsection{Width of the Footing $\left(B_{F}\right)$}

Numerical analyses were carried out on the square footing with varying width by keeping all other parameters such as the depth, location of the excavation and excavation dimensions were constant. Figures 5 and 6 show the vertical and horizontal displacement of the footing respectively. The results presented here are pertaining to the square footings having the dimensions of $1.5 \mathrm{~m} \times 1.5 \mathrm{~m}, 2.0 \mathrm{~m} \times 2.0 \mathrm{~m}, 3.0 \mathrm{~m}$ $\times 3.0 \mathrm{~m}$, while the depth of the footing remaining constant as 1 $\mathrm{m}$. The excavation dimensions were considered of a shorter length of $10 \times 5 \mathrm{~m}$ with $\mathrm{L}_{\mathrm{E}} / \mathrm{B}_{\mathrm{E}}<6$ under three-dimensional condition [3] and a longer length of $40 \times 5 \mathrm{~m}$ with $\mathrm{L}_{\mathrm{E}} / \mathrm{B}_{\mathrm{E}}>6$ (where, $\mathrm{L}_{\mathrm{E}}-$ Length of the excavation, $\mathrm{B}_{\mathrm{E}}-$ Width of the excavation) under plane strain condition [3]. The footing was placed $1.5 \mathrm{~m}$ away from the excavation. The results were interpreted for after completion of every $1 \mathrm{~m}$ depth of excavation till achieving the maximum depth of excavation of $5.0 \mathrm{~m}$.

Table 1. Material properties and dimensions of foundation.

\begin{tabular}{ll}
\hline Property & Description \\
\hline Sheet pile wall & $10.2 \mathrm{~m}$ \\
Length & $0.020 \mathrm{~m}$ \\
Thickness & $78.5 \mathrm{kM} / \mathrm{m}^{3}$ \\
Unit weight & $1.8 \times 10^{11} \mathrm{kN} / \mathrm{m}^{2}$ \\
Young's modulus & 0.30 \\
Poisson's ratio & \\
Soil properties & Mohr-coulomb \\
Model & Drained \\
Behavior & $18 \mathrm{kN} / \mathrm{m}^{3}$ \\
Unit weight $(\gamma)$ & $20 \times 10^{3} \mathrm{kN} / \mathrm{m}^{2}$ \\
Young's modulus $\left(\mathrm{E}_{\mathrm{S}}\right)$ & 0.30 \\
Poisson's ratio $(\mu)$ & $30^{\circ}$ \\
Angle of internal friction $(\phi)$ & \\
Foundation & Square \\
Shape & $1.5 \mathrm{~m}, 2 \mathrm{~m}, 3 \mathrm{~m}$ \\
Width & $1 \mathrm{~m}, 1.5 \mathrm{~m}, 2 \mathrm{~m}, 3 \mathrm{~m}$ \\
Depth & Concrete \\
Type of footing & $\mathrm{M} 30$ \\
Grade of concrete & $27,000 \mathrm{MPa}$ \\
Young's modulus of footing & 0.15 \\
Poisson's ratio & \\
\hline
\end{tabular}

It can be seen from the figures that the impact of excavation is very much higher for smaller footings as compared to the footings of larger dimensions. It can also be noticed that the vertical displacement and the horizontal displacement of the footing is reduced with an increase in width of the footing $\left(\mathrm{B}_{\mathrm{F}}\right)$. The vertical and horizontal displacement of the footing due to the effect of excavation is more in the case of excavation under plane strain condition as compared to three-dimensional condition. Therefore, the reason for an increase in displacements of the footing in the case of excavation under plane strain condition has been further investigated by studying the variation of vertical stress, horizontal stress and shear stresses of soil along with the depth from the footing. Figure 7, Figure 8 and Figure 9 show the variation of vertical stress, horizontal stress and shear stress along the depth from the footing for excavation under three-dimensional condition. Similarly, Figure 10, Figure 11 and Figure 12 show the variation of vertical stress, horizontal stress and shear stress along the depth from the footing for the excavation under plane strain condition. 


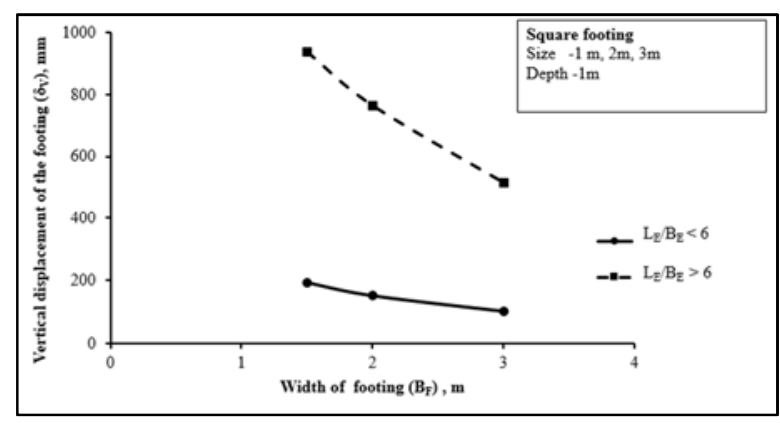

Figure 5. Vertical displacement of square footing in loose sand concerning the width of the footing.

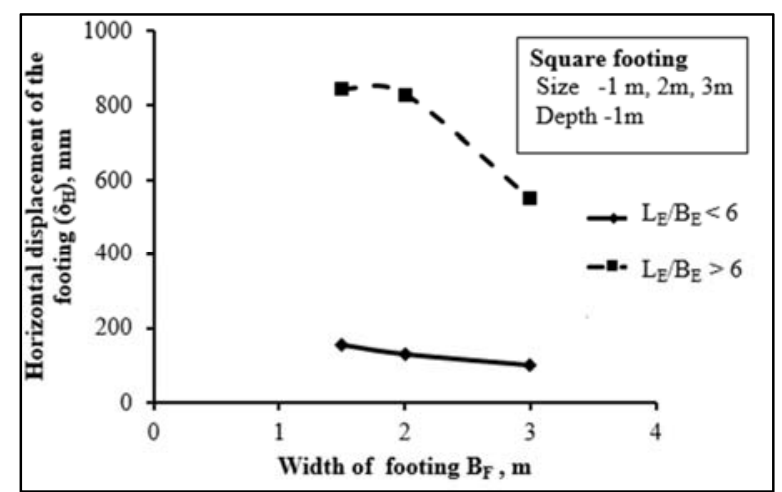

Figure 6. Horizontal displacement of square footing in loose sand concerning the width of the footing.

The stresses as plotted in these figures are pertaining to the variation of stresses that have been examined along the centre of the footing. It can be observed that the vertical stresses, horizontal stresses and shear stresses around the footing uniformly increased after excavation by comparing to the stress conditions before an excavation. This increase in vertical and horizontal stresses is leading directly to an increase in displacements of the footing due to the effect of adjacent excavations. This trend adheres to be common in both the cases of excavation.

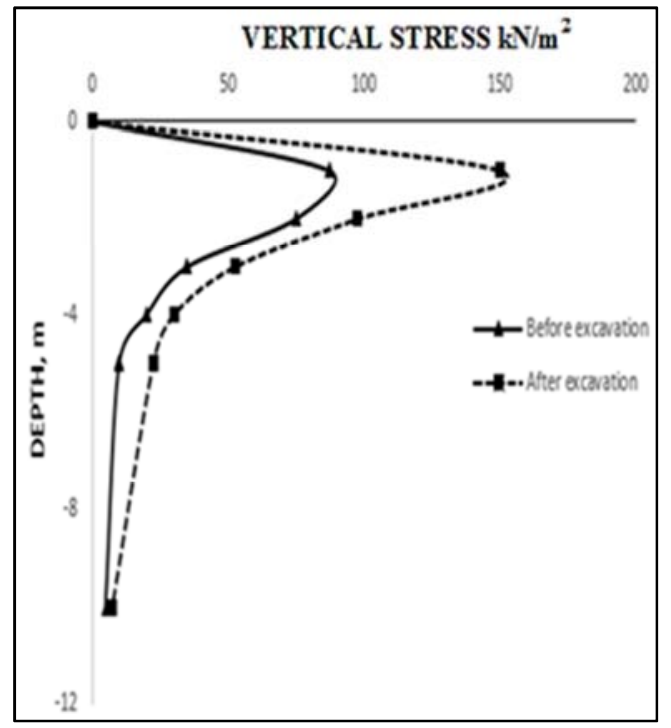

Figure 7. Vertical stress variation along the depth from the footing for excavation with $L_{E} / B_{E}<6$.

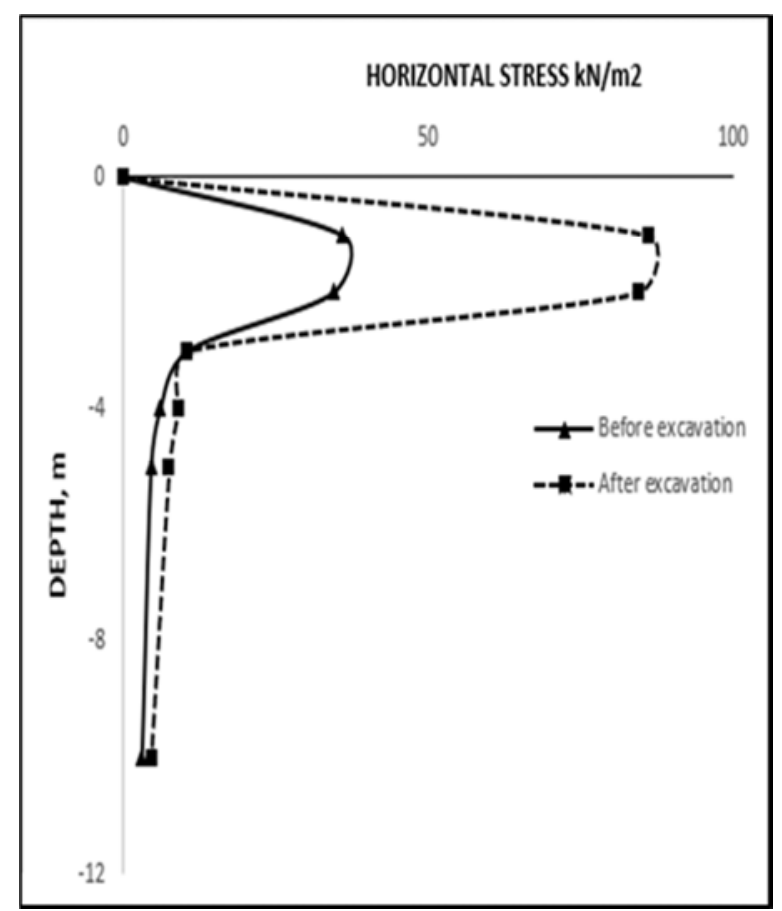

Figure 8. Horizontal stress variation along the depth from the footing for an excavation with $L_{E} / B_{E}<6$.

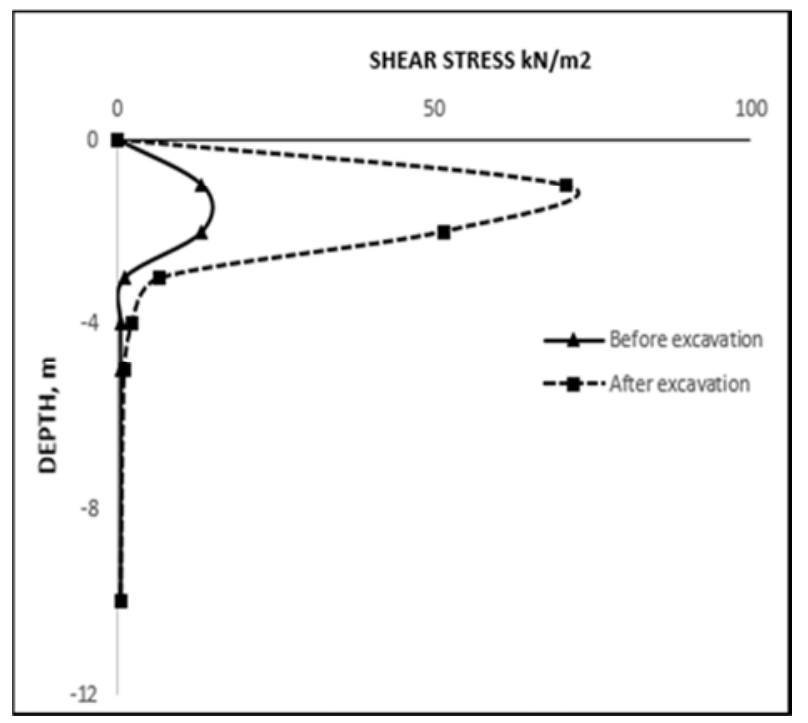

Figure 9. Shear stress variation along the depth from the footing for an excavation with $L_{E} / B_{E}<6$.

However, it can be noticed that the vertical stresses and horizontal stresses are very high in the case of an excavation with $\mathrm{L}_{\mathrm{E}} / \mathrm{B}_{\mathrm{E}}>6$ as compared to the $\mathrm{L}_{\mathrm{E}} / \mathrm{B}_{\mathrm{E}}<6$. Further, it can be noticed from Figure 9 and Figure 12 that the shear stresses along the depth of a square footing in case of an excavation with $\mathrm{L}_{\mathrm{E}} / \mathrm{B}_{\mathrm{E}}<6$ is higher as compared to the $\mathrm{L}_{\mathrm{E}} / \mathrm{B}_{\mathrm{E}}>6$. This increase in shear stresses in the case of an excavation with $\mathrm{L}_{\mathrm{E}} / \mathrm{B}_{\mathrm{E}}<6$ is leading to lesser displacements as compared to the case of $\mathrm{L}_{\mathrm{E}} / \mathrm{B}_{\mathrm{E}}>6$. This is mainly attributed to the higher mobilization of shear resistance against excavation load in the case of an excavation with $\mathrm{L}_{\mathrm{E}} / \mathrm{B}_{\mathrm{E}}<6$ as compared to the case of $\mathrm{L}_{\mathrm{E}} / \mathrm{B}_{\mathrm{E}}>6$. 


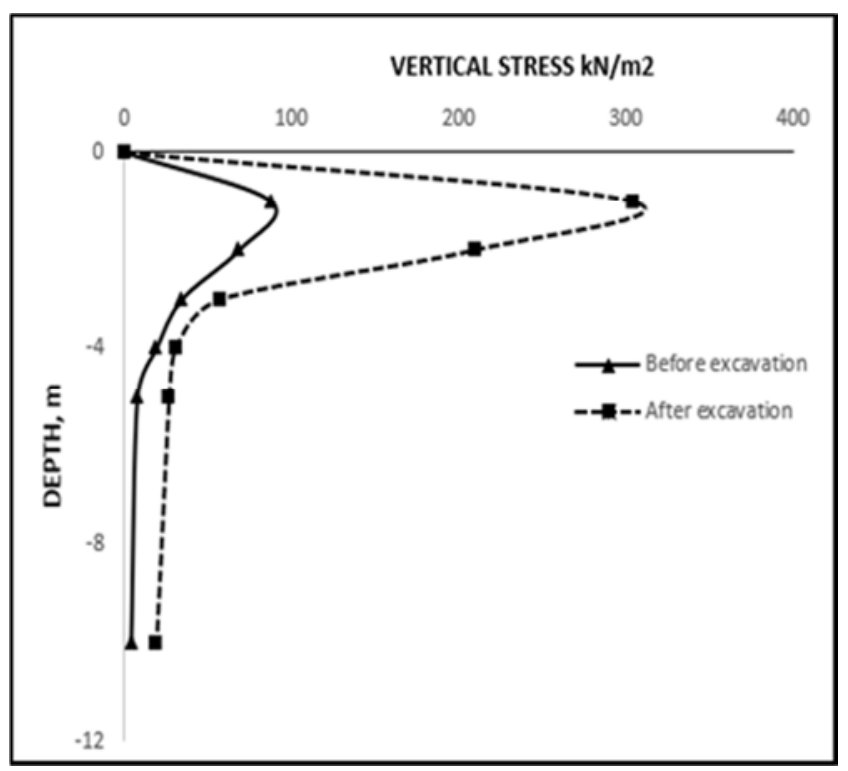

Figure 10. Vertical stress variation along the depth from the footing for an excavation with $L_{E} / B_{E}>6$.

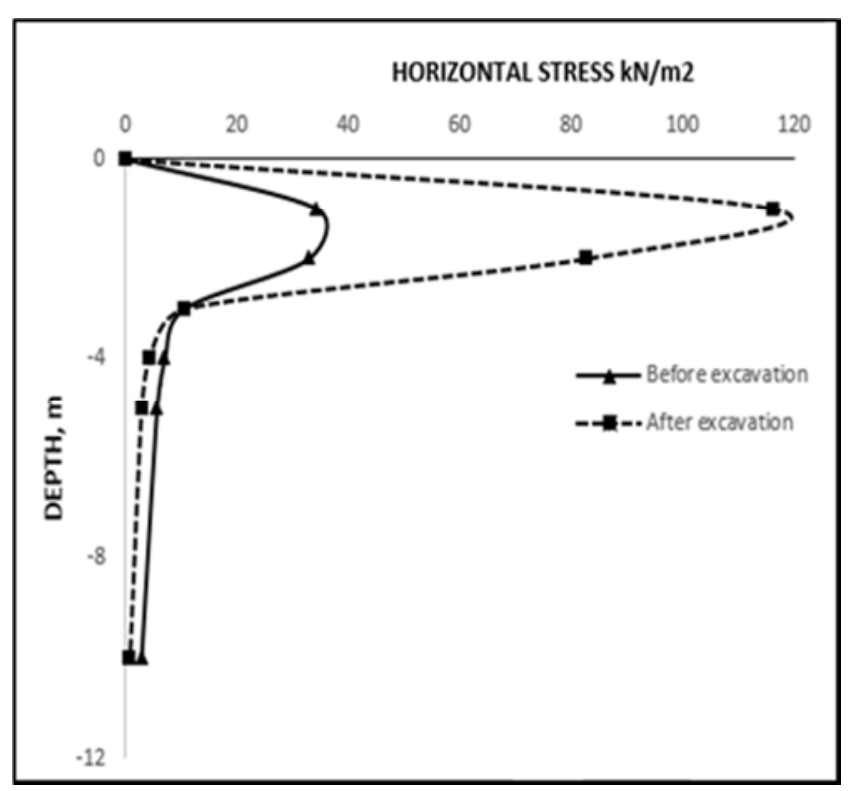

Figure 11. Horizontal stress variation along the depth from the footing for an excavation with $L_{E} / B_{E}>6$.

\subsection{Depth of the Footing}

Numerical analyses were carried out by varying the depth of the footing and keeping all other parameters constant. The excavation dimensions were $10 \times 5 \mathrm{~m}$ with $\mathrm{L}_{\mathrm{E}} / \mathrm{B}_{\mathrm{E}}<6$ and $40 \times$ $5 \mathrm{~m}$ with $\mathrm{L}_{\mathrm{E}} / \mathrm{B}_{\mathrm{E}}>6$ and the depth of excavation was $5 \mathrm{~m}$. The footing was placed at a distance of $0.5 \mathrm{~m}$ away from the excavation. To obtain the desired results, a separate numerical analysis has been carried out on the footing with varying depths of the footing.

Figure 13 and Figure 14 shows the vertical and horizontal displacement of the footing for varying depth of the footing. The results presented in these figures pertain to square footings having a dimension of $3.0 \mathrm{~m} \times 3.0 \mathrm{~m}$ with depth varied by $1.0 \mathrm{~m}, 2.0 \mathrm{~m}$ and $3.0 \mathrm{~m}$.

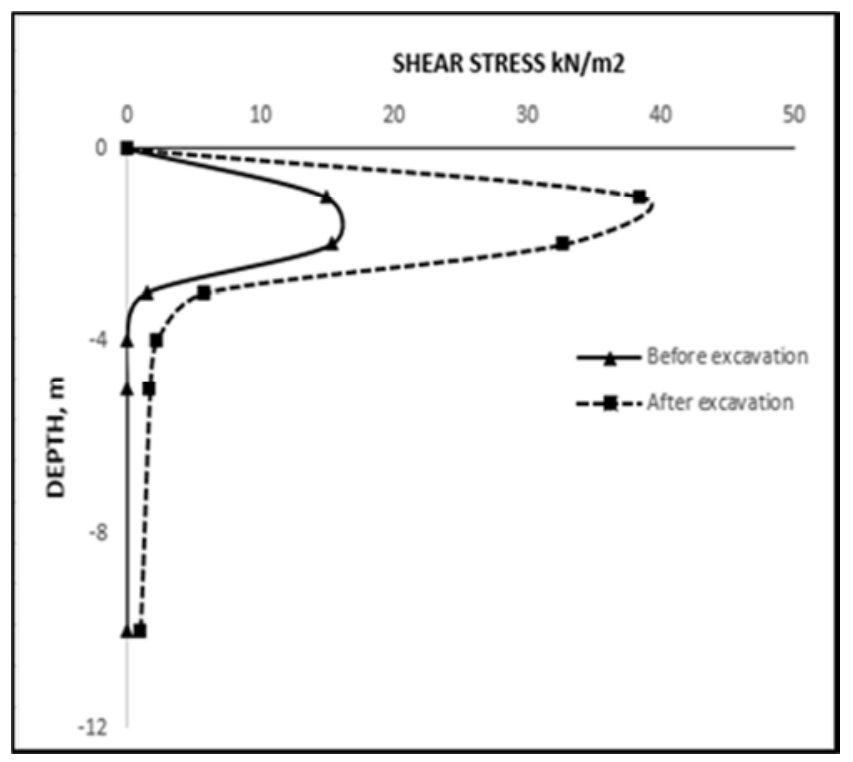

Figure 12. Shear stress variation along the depth from the footing for an excavation with $L_{E} / B_{E}>6$.

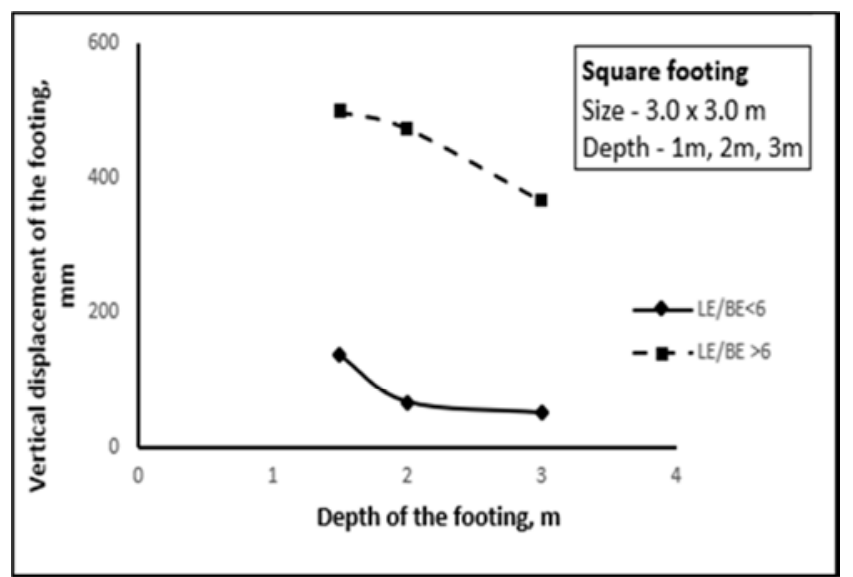

Figure 13. Vertical displacement of the square footing in loose sand concerning the depth of footing.

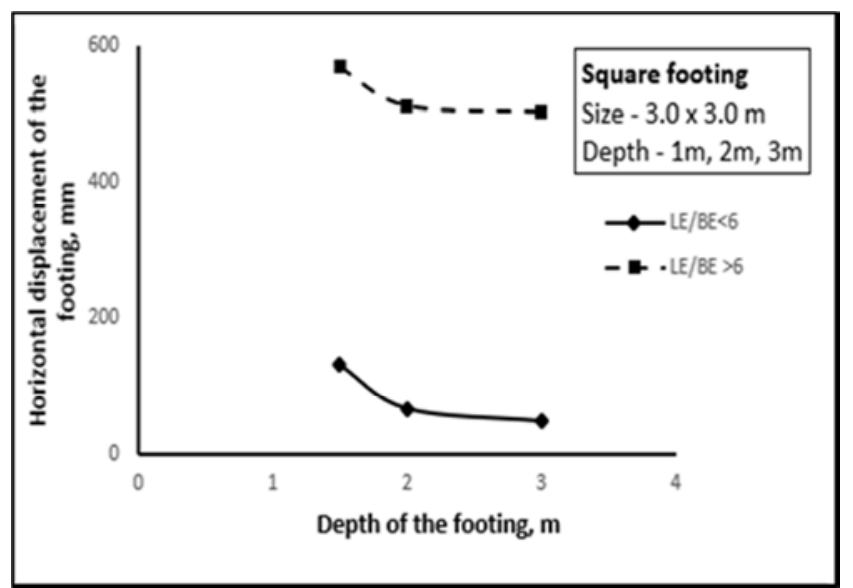

Figure 14. Horizontal displacement of the square footing in loose sand to the depth of footing.

It can be seen from the figures that the effect of depth of the footing is inversely proportional to both the vertical and horizontal displacement of the footing. i.e the impact of 
excavation on the footing is higher in the case of the footing placed at shallow depth as compared to the deeper depth. The influence of excavation on the footing is more in the case of an excavation with $L_{E} / B_{E}>6$ as compared to $L_{E} / B_{E}<6$. The reason for the reduced displacement of the footing with an increase in depth of the footing is due to a reduced ground movement with the increase in depth. This is mainly attributed to an increase in confinement effect with an increase in depth below the ground surface.

\subsection{Depth of Excavation $\left(D_{E}\right)$}

The effect of depth of excavations on the square footings have been studied by keeping the location of the footing from an excavation as constant and dimensions of the excavations were of plane strain condition with $\mathrm{L}_{\mathrm{E}} / \mathrm{B}_{\mathrm{E}}>6$ and three-dimensional condition with $\mathrm{L}_{\mathrm{E}} / \mathrm{B}_{\mathrm{E}}<6$. Numerical analyses were carried out for the square footing with dimensions of $1.5 \mathrm{~m} \times 1.5 \mathrm{~m}$, depth of $1 \mathrm{~m}$ and excavations carried out up to a maximum depth of $5 \mathrm{~m}$ in both the cases $\mathrm{L}_{\mathrm{E}} / \mathrm{B}_{\mathrm{E}}<6$ and $\mathrm{L}_{\mathrm{E}} / \mathrm{B}_{\mathrm{E}}>6$. The footing was placed at a distance of $0.5 \mathrm{~m}$ away from the excavation.

Figure 15, Figure 16 and Figure 17 show the vertical displacement, horizontal displacement and bending moment of the footing respectively to the depth of excavation. It can be observed from the Figure. 15 and Figure 16 that the influence of adjacent excavation on the footing is directly proportional to the depth of excavation and found to follow the same trend. This trend is observed to be common for both the vertical and horizontal displacement of the footing. In general, the vertical and horizontal displacement of the footing is increasing with an increase in the depth of excavation.

It can be further noticed from Figure 15 and Figure 16 that the effect of depth excavation is significant in both the cases of excavation dimension ratio of $\mathrm{L}_{\mathrm{E}} / \mathrm{B}_{\mathrm{E}}<6$ and $\mathrm{L}_{\mathrm{E}} / \mathrm{B}_{\mathrm{E}}>6\left(\mathrm{~L}_{\mathrm{E}}-\right.$ Length of the excavation, $\mathrm{B}_{\mathrm{E}}-$ width of the excavation). Also, the vertical and horizontal displacement of the footing is very much higher for an excavation with $\mathrm{L}_{\mathrm{E}} / \mathrm{B}_{\mathrm{E}}>6$ as compared to the $\mathrm{L}_{\mathrm{E}} / \mathrm{B}_{\mathrm{E}}<6$. Figure. 17 shows the variation of bending moment of the footing to the depth of excavation. However, the trend for bending moment of the footing is quite different as compared to the displacement of the footing.

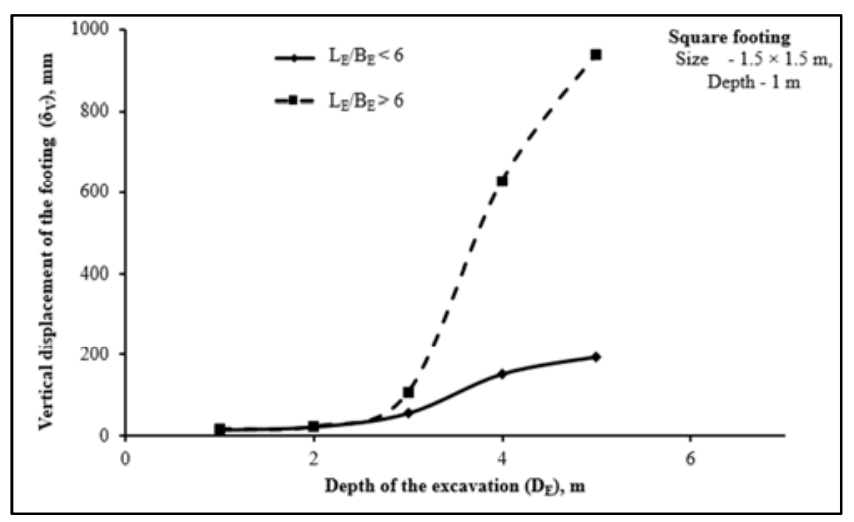

Figure 15. Vertical displacement of the square footing in loose sand to depth of excavation.

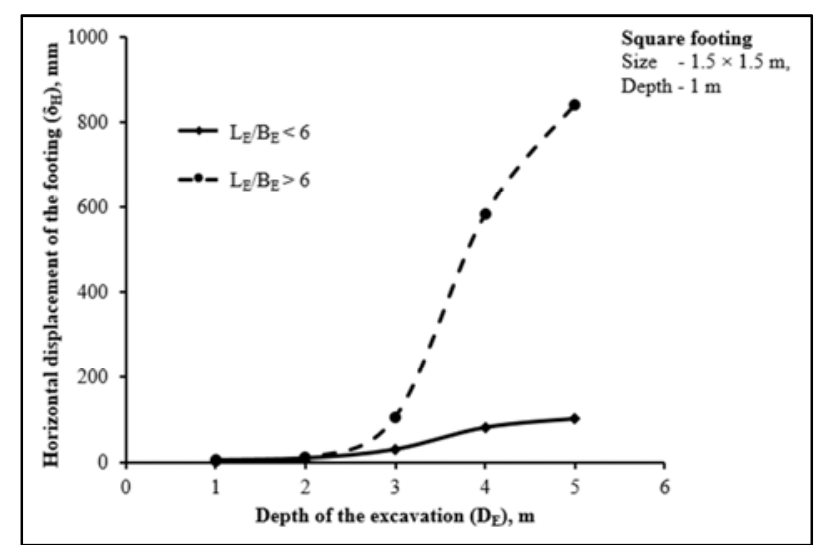

Figure 16. Horizontal displacement of the square footing in loose sand to the depth of excavations.

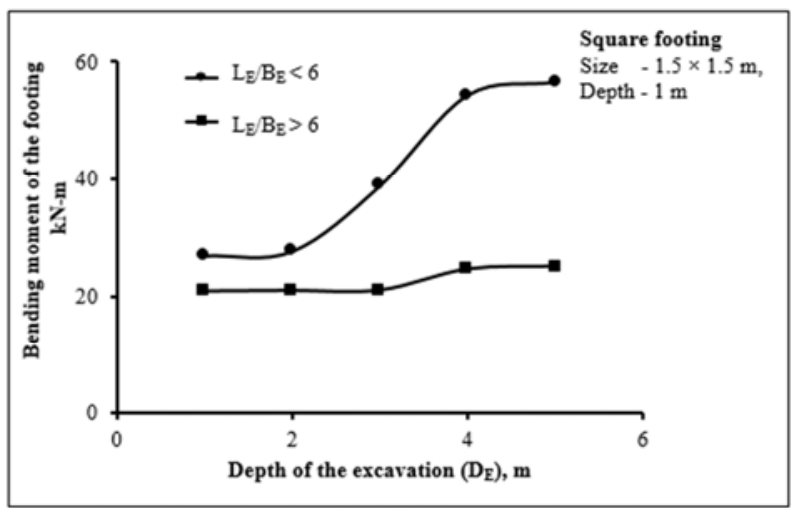

Figure 17. Bending moment of the square footing in loose sand to the depth of excavation.

Here, the impact of excavation on the bending moment of the footing is higher in the case of the excavation with $\mathrm{L}_{\mathrm{E}} / \mathrm{B}_{\mathrm{E}}$ ratio less than 6 as compared to the $\mathrm{L}_{\mathrm{E}} / \mathrm{B}_{\mathrm{E}}$ ratio greater than 6 . This may be because the in-situ stress conditions for $L_{E} / B_{E}<6$ is three dimensional [3]. Also, it is observed that the effect of excavation dimensions on the response of the footing is very significant at deeper depths when compared to at shallow depths of excavation [12].

\subsection{Footing Location}

In conventional practices, footings are planned and designed to take vertical loads of the structures and examined for settlement and verified whether it lies within the allowable limit as per the structural design codes [13]. Considering the same, maximum bending moment and the maximum vertical settlement induced on the footing due to an adjacent excavation, the footing placed at different distances $\left(\mathrm{X}_{\mathrm{F}}\right)$ away from the excavation faces were analyzed. A separate numerical analysis was carried out for each location of the footing from an excavation as illustrated in Figure 18. The analysis has been performed on square footing having a dimension of $1.5 \mathrm{~m} \times 1.5$ $\mathrm{m}$, depth of the footing $1.0 \mathrm{~m}$ and excavation dimensions were of $10.0 \times 5.0 \mathrm{~m}$ with $\mathrm{L}_{\mathrm{E}} / \mathrm{B}_{\mathrm{E}}<6$ and $40.0 \times 5.0 \mathrm{~m}$ with $\mathrm{L}_{\mathrm{E}} / \mathrm{B}_{\mathrm{E}}>6$ with a maximum depth of excavation $5.0 \mathrm{~m}$.

For a better understanding of the quantitative results, curves of vertical settlement and bending moment versus the footing 
location from the excavation were plotted. Figure. 19 and Figure 20 shows the settlement and bending moment of the footing location from an excavation. It is noticed from Figure19 and Figure 20 that the settlement and bending moment of the footing are decreased with an increase in distance of the footing location from an excavation. It can also be seen from the figures that the effect of excavations on the footing is more prominent in the case of the excavation with $\mathrm{L}_{\mathrm{E}} / \mathrm{B}_{\mathrm{E}}>6$ when compared to the $\mathrm{L}_{\mathrm{E}} / \mathrm{B}_{\mathrm{E}}<6$.

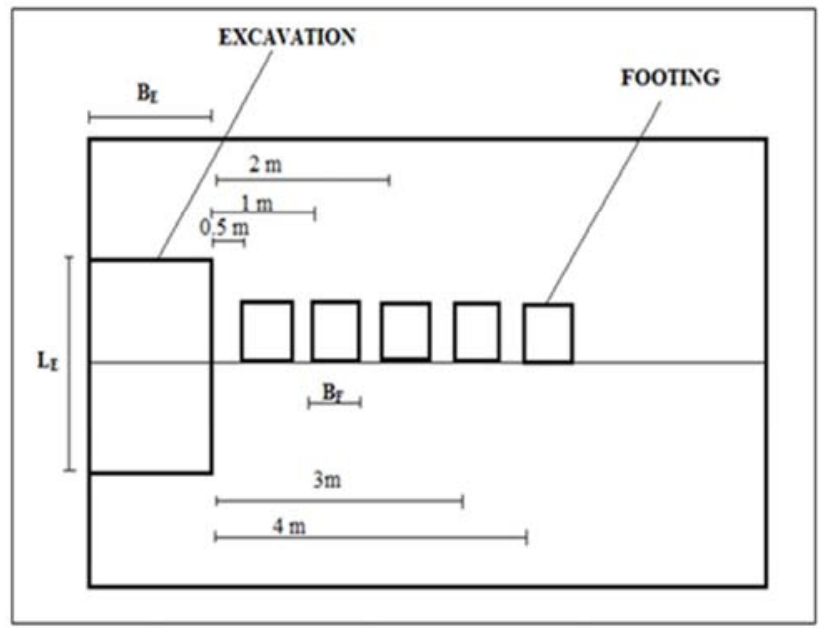

Figure 18. Top view of the location of the square footing from an excavation.

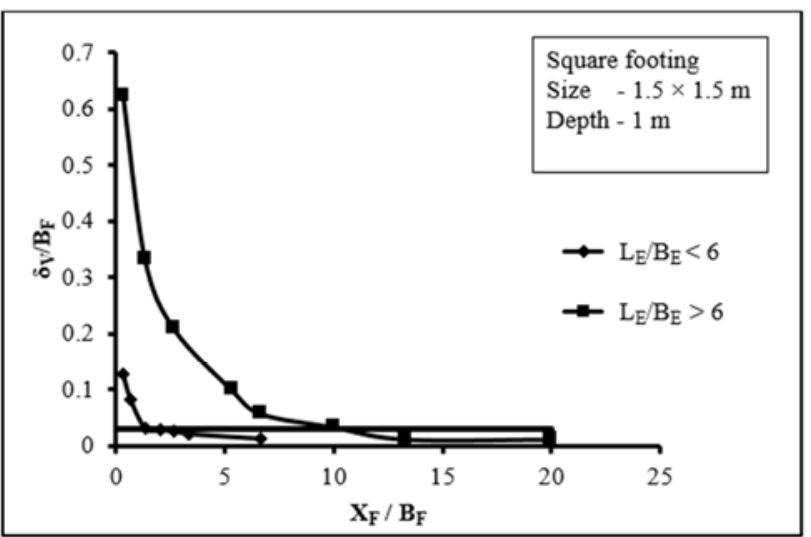

Figure 19. Vertical displacement of the square footing in loose sand to the location of the footing from an excavation.

The horizontal line in Figure 20 representing the maximum vertical settlement of the footing under direct structural load is plotted mainly to understand and assess the safe distance of the footing from the adjacent excavation. The major concern is to study whether the footing designed exclusively for the structural load is safe for an added load due to the effect of excavation. Also, to arrive at a safe distance at which the excavation is to be done from the footing. For estimating the safe location of the footing from the excavation in sand a permissible settlement of $50 \mathrm{~mm}$ is considered [14].

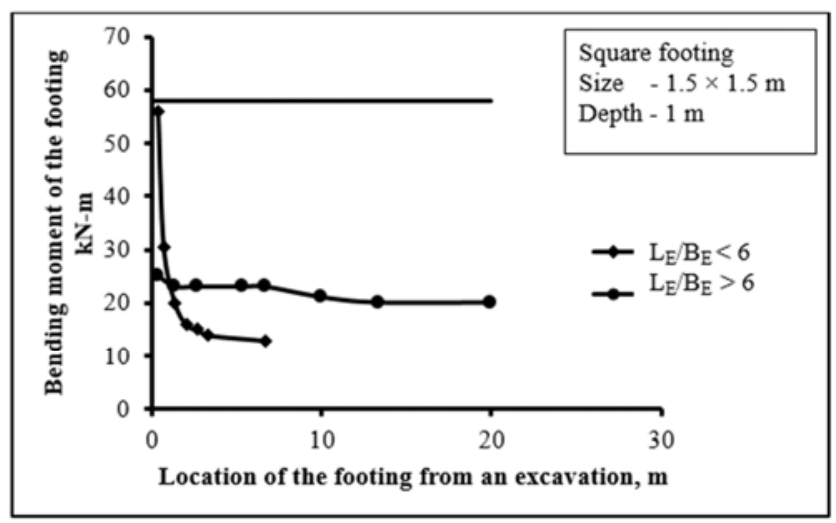

Figure 20. Bending moment of the square footing in loose sand to the location of the footing from an excavation.

The straight horizontal line in Figure 19 shows the maximum permissible settlement of an isolated footing. It can be observed from the figure that the footings whose placement, when it falls above the horizontal line are unsafe as it exceeds the permissible limit. Also, the footing whose settlement falls below the horizontal line indicates that they are safe as they are within the permissible $50 \mathrm{~mm}$ settlement.

Similarly, Figure 20 shows the bending moment of the footing with varying distances of the footing from the excavation for both the case of $\mathrm{L}_{\mathrm{E}} / \mathrm{B}_{\mathrm{E}}<6$ and $\mathrm{L}_{\mathrm{E}} / \mathrm{B}_{\mathrm{E}}>6$. It can be noticed from the figure that the bending moment of the footing is reduced with an increase in distance from the excavation. The straight line in Figure 20 represents the footing's maximum moment capacity. It is intriguing to note that the footing's bending moment which falls below the horizontal line is safe against the bending moment. The safe location of the square of the footing to the width, based on an allowable settlement limit of $50 \mathrm{~mm}$ as tabulated and presented in Table 2. From the table, we can notice that with an increase in the width of the footing the safe location of the footing from the excavation decreases. Also, as it may be seen that the footing's safe location is much closer to excavation in the case of the $\mathrm{L}_{\mathrm{E}} / \mathrm{B}_{\mathrm{E}}<6$ as compared to the case of $\mathrm{L}_{\mathrm{E}} / \mathrm{B}_{\mathrm{E}}>6$. The main design concern is to study the behaviour of the footing subjected to adjacent excavation is safe against it or not.

Table 2. Safe Location of the Footing Based on Width of the Footing.

\begin{tabular}{|c|c|c|c|}
\hline \multirow{2}{*}{ Size } & \multirow{2}{*}{ Depth } & \multicolumn{2}{|c|}{ Safe location of footing from an excavation from the basis of allowable settlement $\left(X_{L} / B_{F}\right)$} \\
\hline & & $\mathbf{L}_{\mathrm{E}} / \mathbf{B}_{\mathrm{E}}<\mathbf{6}$ & $\left(\mathbf{L}_{E} / \mathbf{B}_{\mathrm{E}}>6\right)$ \\
\hline $1.5 \times 1.5$ & 1 & 1.3 & 10 \\
\hline $2.0 \times 2.0$ & 1 & 1.0 & 5 \\
\hline $3.0 \times 3.0$ & 1 & 0.78 & 4.5 \\
\hline
\end{tabular}

Therefore, the quantitative results were made clear to examine the safe positioning of the footing from the excavation based on a permissible settlement [14] and the moment of resistance. 


\subsection{Settlement Criteria}

Normally, footings are designed by satisfying two criterions such as settlement and shear. The settlement criteria are more critical for the footing resting on the sand. Hence, the settlement of the footing due to the effect of an adjacent excavation is very important and need to be examined. Therefore, the maximum vertical settlement, differential settlement and angular distortion of the footing due to the effect of excavation has been examined for a square footing and are given in Table 3.

Table 3. Settlement of Existing Footing from the Effect of an Adjacent Excavation of $L_{E} / B_{E}<6$ (Influenced Zone) [16].

\begin{tabular}{llll}
\hline Settlement & Before excavation $(\mathbf{m m})$ & After excavation $(\mathbf{m m})$ & Permissible limit $(\mathbf{m m})$ \\
\hline Settlement of the footing & 14 & 125 & 50 \\
Differential settlement & 0.542 & 83.483 & 2.25 \\
Angular distortion (Tilt) & 0.00036 & 0.055 & 0.0015 \\
\hline
\end{tabular}

The settlement analysis has been performed for $1.5 \mathrm{~m}$ wide square footing, depth of the footing $1.0 \mathrm{~m}$ and the footing is placed at $1 \mathrm{~m}$ away from an excavation in case of the $\mathrm{L}_{\mathrm{E}} / \mathrm{B}_{\mathrm{E}}<6$. The results are comparing with the prescribed allowable settlement of the footing in the sand [14]. It can be observed from the table that the maximum settlement, differential settlement and angular distortion of the footing due to the effect of excavation is increased significantly as compared to the permissible limit. It is seen from the table that the effect of excavation on the settlement of the footing is increased significantly. Therefore, proper precautions need to be taken to protect the existing building well before excavation starts for new constructions adjacent to the footing on loose sand.

\section{Conclusions}

The behaviour of existing square footing due to the effect of an adjacent excavation has been analyzed in the paper using the PLAXIS3D programme. Based on the numerical results, the following conclusions are drawn.

The influence of new construction closer to the existing footing in terms of excavations is very prominent on settlement of the footings resting on loose sand. However, the influence is mainly dependent on the excavation dimension, depth of the excavation and other parameters such as the width and depth of the footing.

There is a prominent increase in vertical and horizontal displacement of the existing footing due to the effect of an adjacent excavation. But, this trend is very significant in the case of an excavation with $\mathrm{L}_{\mathrm{E}} / \mathrm{B}_{\mathrm{E}}$ ratio greater than 6 as compared to the $\mathrm{L}_{\mathrm{E}} / \mathrm{B}_{\mathrm{E}}$ less than 6 .

The effect of excavation on the bending moment of the footing is much higher in the case of an excavation with $\mathrm{L}_{\mathrm{E}} / \mathrm{B}_{\mathrm{E}}<6$ as compared to the $\mathrm{L}_{\mathrm{E}} / \mathrm{B}_{\mathrm{E}}>6$. In general, an excavation nearer to the existing footing is to increase the bending moment of the footing.

The change in ground conditions in terms of vertical, horizontal and shear stresses in soil closer to the footing due to an adjacent excavation is found to be very high as compared to before an excavation.

The vertical and horizontal displacement of existing square footing is reduced with an increase in the location of the footing from an excavation.

The location at which the existing square footing is safer from an excavation has been examined based on the settlement criteria and found to be more in the case of an excavation with $\mathrm{L}_{\mathrm{E}} / \mathrm{B}_{\mathrm{E}}$ ratio greater than 6 as compared to the $\mathrm{L}_{\mathrm{E}} / \mathrm{B}_{\mathrm{E}}$ ratio less than 6 .

The safe location of the footing from an excavation is found to be $1.3 \mathrm{~m}$ in the case of excavation under three-dimensional conditions with $\mathrm{L}_{\mathrm{E}} / \mathrm{B}_{\mathrm{E}}$ ratio less than 6 and $10 \mathrm{~m}$ in the case of excavation under plane strain condition with $\mathrm{L}_{\mathrm{E}} / \mathrm{B}_{\mathrm{E}}$ ratio greater than 6 for the footing with the least dimensions of 1.5 $\mathrm{m}$ considered in the analysis.

\section{References}

[1] Faheem, Caia, Ugaia, Hagiwarab (2003). Two-dimensional base stability of excavations in soft soils using FEM, Computers and Geotechnics, Vol. 30, pp. 141-163.

[2] Yoo, Lee (2007). Deep excavation-induced ground surface movement characteristics - a numerical investigation, Computers and Geotechnics, Vol. 35, pp. 231-252.

[3] Faheem, Cai, Ugai (2004). Three-dimensional base stability of rectangular excavations in soft soils using FEM, Computers and Geotechnics, Vol. 31, pp. 67-74.

[4] Goh. A (1990). Assessment of basal stability for braced excavation systems using FEM, Computers and Geotechnics, Vol. 10, pp. 325-338.

[5] Dinakar. K N, Prasad. S K (2014). Behavior of tie back sheet pile wall for deep excavation using plaxis, International Journal of Research in Engineering and Technology, Vol. 3, pp. 97-103.

[6] Arai, Kusakabe, Murata, Konishi (2007). A numerical study on ground displacement and stress during and after the installation of deep circular diaphragm walls and soil excavation, Computers and Geotechnics, Vol. 35, pp. 791-807.

[7] Jardaneh (2006). Assessment of local excavation support systems: a case study of Nablus city, Palestine, An - Najah Univ. J. Res. (Science) Vol. 20, pp. 101-126.

[8] Godavarthi, Mallavalli, Peddi, Katragadda, and Mulpuru (2011). Contiguous pile wall as a deep excavation supporting system, Leonardo Electronic Journal of Practices and Technologies, pp. 144-160.

[9] Jenniferthiede (2014). Minard hall façade collapse', http://failures. Wikispaces.com/minard+hall+facade+collapse.

[10] Mostafa, Ashraf K. Nazir (2011). The effect of deep excavation-induced lateral soil movements on the behaviour of strip footing supported on reinforced sand, Journal of Advanced Research, Vol. 3, pp. 337-344. 
[11] Sathiya G and Karthigeyan S (2019). Effect of excavation on the response of circular footing in sandy soil, published in part of the 'Lecture Notes in Civil Engineering Book Series on Geotechnical Applications (IGC2016, Vol. 4)', pp. 109-116, Springer Nature Singapore Pte Ltd. 2019.

[12] Bin Chen Benson Hsuing, Sy- Dan Dao (2016), Influence from three-dimensional effect on the wall deflection induced by a deep excavation in Kaohsuing, Taiwan, The $15^{\text {th }}$ Asian Regional Conference on Soil Mechanics and Geotechnical Engineering "Japnese Geotechnical Society Special Publication" (Vol 2, Issue 45); pp 1602-1607.
[13] IS 456 (2000), 'Plain and reinforced concrete code of practice'.

[14] IS 1904 (1986). Code of practice for design and construction of foundations in soils: general requirements.

[15] IS 6403 (1981). Code of practice for determination of bearing capacity of shallow foundations.

[16] IS 8009 part-I (1976). Code of practice for calculation of settlements of foundations. 